\title{
SIGNOS DO CONSUMO, NARRATIVIDADE, GÊNEROS E VIDA SIMBÓLICA
}

\author{
Eneus Trindade ${ }^{1}$ \\ Clotilde Perez ${ }^{2}$
}

Ao ler um livro de Lúcia Santaella em 1996, intitulado Cultura das mídias, lembro-me em um dos capítulos da citação que ela faz de um astrônomo - Michael D. Papagiannis que dizia que toda vibração acima de temperaturas maiores que o zero absoluto é um índice de vida e, portanto, um signo de vida. Nesse sentido, podemos dizer que os artigos desta segunda edição de 2013 da Revista Signos do Consumo trazem o sentido da vitalidade sígnica em visões plurais da nossa semiosfera, que se dá a partir de estudos que refletem sobre: as narrativas e o corpo na publicidade, nas dinâmicas sociais de sentidos das relações de gênero e no consumo em si em suas formas mais criativas. O primeiro texto a abrir a edição Transformar sim, perder a essência jamais: o conto de chapeuzinho vermelho como texto publicitário de João Batista Freitas Cardoso, Professor no Programa de Mestrado em Comunicação da Universidade Municipal de São Caetano do Sul e de Danuza Pessoa Polistchuk Mestranda em comunicação pela mesma universidade apresenta como os contos de fadas, enquanto códigos culturais, podem ser identificados e reconhecidos, mesmo com as mudanças sofridas ao longo do tempo, por meio da análise de seis peças publicitárias que têm o conto Chapeuzinho Vermelho como conceito criativo.

O segundo texto Relações de gênero e consumo na publicidade da Brahma na copa do mundo de 2010 de Camila Augusta Alves Pereira - Mestre em Comunicação Social pela Universidade do Estado do Rio de Janeiro, Fausto Amaro e Fábio Grotz Mestrandos do Programa de Pós-Graduação em Comunicação da mesma universidade, trata do trinômio representações de gênero, esportes e publicidade, evidenciando as construções de gênero e as marcações de uma suposta identidade nacional hegemônica

\footnotetext{
${ }^{1}$ Professor Doutor do Departamento de Relações Públicas, Propaganda e Turismo da ECA/USP. Possui pós-doutorado em Antropologia Visual pela Universidade Aberta de Portugal. Doutor e Mestre em Comunicação pela ECA/USP. Docente do PPGCOM/ECA/USP na área de teoria e pesquisa em comunicação e Coordenador do Grupo Interdisciplinar de Estudos da Linguagem Publicitária $\mathrm{CNPq} / \mathrm{ECA} / \mathrm{USP}$.

${ }^{2}$ Professora Livre Docente em Ciências da Comunicação do Departamento de Relações Públicas, Propaganda e Turismo da ECA/USP. Possui pós-doutorado em Comunicação pela Universidade de Murcia-Espanha. Doutora em Comunicação e Semiótica pela PUC-SP, Mestre em Administração pela PUC-SP. Docente do PPGCOM/ECA/USP na área de interfaces sociais da comunicação. Coordenadora dos Grupos de Estudos Semióticos em Comunicação, Cultura e Consumo CNPq/ECA/USP.
} 
Signos do consumo, narratividade, gêneros e vida simbólica

de Eneus Trindade e Clotilde Perez

presentes nos dois filmes publicitários da marca Brahma escolhidos (Lista de Pedidos e Poucas Palavras).

$\mathrm{O}$ artigo três, Corpo, publicidade e consumo tecnológico de Wilton Garcia Professor do Mestrado em Comunicação e Cultura da Universidade de Sorocaba-SP, é um ensaio "que aponta considerações sobre o corpo na publicidade contemporânea, ao observar algumas estratégias discursivas no campo da comunicação, em especial a imagem", a partir da crítica ao consumo tecnológico, tendo o anúncio publicitário Birdman da marca Coca-Cola como objeto de leitura e análise.

$\mathrm{O}$ artigo seguinte aborda a questão dos signos da diferenciação institucional de marca por meio do artigo $O$ marketing cultural como elemento de diferenciação: o case "Bradesco - espetáculo como mensagem” de Flavi Ferreira Lisboa Filho - Professor no Programa de Pós-Graduação em Comunicação e no Departamento de Ciências da Comunicação da Universidade Federal de Santa Maria e Julia Munareto Leal - Mestre pelo Programa de Pós-Graduação em Comunicação da UFSM. O texto apresenta uma revisão bibliográfica "com a apresentação de conceitos e definições sobre o tema marketing cultural com vistas à comunicação organizacional”. Para contextualizar o apanhado teórico os autores apresentam o caso prático do Banco Bradesco, que iniciou reestruturação geral a fim de legitimar a adoção de um novo conceito, o de 'banco completo'. Este novo conceito passou então a definir o posicionamento estratégico do banco/marca no mercado.

O quinto artigo, Da propaganda à "publicidade" política: a ideia de consumo e descarte na campanha eleitoral de Haddad, de Diógenes José Pasqualini - Doutorando em Comunicação e Semiótica pela Pontifícia Universidade Católica de São Paulo, trata de forma instigante da correlação entre os universos sígnicos da política e da publicidade de automóveis pelo estudo da última campanha eleitoral municipal de São Paulo de Fernando Haddad em 2012 e a publicidade da marca Ford, buscando analisar com se dá o processo de "identificação da propaganda política com os discursos publicitários no desencadeamento do efeito cíclico entre desejo, consumo e posterior "descarte" do político.

Já no sexto artigo, Juventude rural e novas formas de sociabilidade mediadas pelas tics de Ezequiel Redin - Doutorando em Extensão Rural pela Universidade de Federal de Santa Maria, Paulo Roberto Cardoso da Silveira - Professor da Universidade Federal de Santa Maria, Gisele Martins Guimarães - Professora Adjunta na Universidade Estadual do Rio Grande do Sul e Vilson Flores dos Santos - Mestre em 
Signos do consumo, narratividade, gêneros e vida simbólica

de Eneus Trindade e Clotilde Perez

Extensão Rural pela Universidade Federal de Santa Maria, apresenta resultados de pesquisa coletiva e interdisciplinar com foco no consumo midiático de jovens da região rural do Centro da Serra do Rio Grande do Sul. O trabalho analisou "as mudanças nas formas de sociabilidade vivenciadas em um processo de transformação da vida rural provocado pela universalização do uso das TICs".

O penúltimo artigo, intitulado Leia na minha camisa - comunicação, consumo e subversão de sentido de marcas absolutas de Irene Carballido - Mestranda em Comunicação e Consumo do PPGCOM- ESPM-SP temos uma discussão criativa sobre produção de sentido feita pelo nome da marca em camisetas e seu poder de subversão no universo da produção sentido em torno da mercadoria e suas contradições.

No último artigo, voltamos à questão das representações do gênero na mídia com o texto A foto errada na capa certa: casamento gay, fetichismos visuais e produção de sentido na recepção midiática de Camilo Vannuchi - Mestrando do Programa de PósGraduação em Ciências da Comunicação da Universidade de São Paulo, que reflete sobre como "a foto publicada numa capa de revista pode influenciar negativamente as práticas de consumo da edição ao permitir que a produção de sentido (na recepção) contradiga o pretendido pelo emissor (na enunciação). Comparamos duas capas sobre o mesmo tema, publicadas por revistas distintas (a Time e a Época São Paulo), combinando semiótica, análise do discurso e teorias da enunciação", recorrendo à teoria da enunciação da recepção publicitária para sugerir sua aplicação no estudo da recepção jornalística.

Por fim, a revista encerra com a resenha intitulada Cultura, marcas e pirataria: o consumo que não tem preço de Diogo Kawano - Mestrando do Programa de PósGraduação em Ciências da Comunicação da Universidade de São Paulo que faz sua apreciação da obra coletiva - Universo Sígnico da Pirataria: Falso? Verdadeiro! Organizada por Clotilde Perez, Eneus Trindade, Jôse Fogaça e Leandro Batista, editado pela InMod, São Paulo, 2013, referente ao trabalho realizado entre 2011 e 2013 pelo Grupo de Estudos Semióticos em Comunicação, Cultura e Consumo-GESC ${ }^{3} / C N P q$, no âmbito da Pós-Graduação em Ciências da Comunicação da Universidade de São Paulo.

A Revista Signos do Consumo segue firme em seu propósito de promover a divulgação científica sobre os fenômenos da publicidade, da circulação das marcas e dos consumos midiáticos e midiatizados. Para tanto, a equipe editorial tem lutado para conquistar alguns espaços na cena da divulgação científica comunicacional, a saber: a Revista está sediada no Portal Sibi de Revistas da USP e obteve D.O.I (Digital Object 
Signos do consumo, narratividade, gêneros e vida simbólica

de Eneus Trindade e Clotilde Perez

Identifier) que é um padrão para identificação de documentos em redes de computadores, como a Internet, para seus artigos a partir de 2013 e também em 2013 a revista obteve avaliação webqualis CAPES periódicos no extrato B2 para a área de Ciências Sociais Aplicadas I, sendo classificada nos extratos B3 para a área Interdisciplinar e B5 nas áreas de Sociologia, Administração, Contábeis, Turismo, Antropologia e Arqueologia.

Todo esse trabalho de qualidade só se torna possível graças aos esforços de todos que fazem a revista acontecer, sobretudo, pela contribuição dos avaliadores nacionais e estrangeiros que participam do comitê de avaliação deste periódico e que, neste momento, manifestamos nominalmente nossos maiores agradecimentos pelo trabalho realizado. Esses professores doutores são: Adolpho Queiroz (Universidade Presbiteriana Mackenzie), Arlete Petry (USP), Aryovaldo De Castro Azevedo Jr. (UFPR), Asdrúbal Borges Formiga Sobrinho (UNB), Gino Giacomini Filho (USCS e USP), Luiz Alberto de Farias (USP), Maria Aparecida Ferrari (USP), Maria Berenice Costa Machado (UFRGS), Maria Ogécia Drigo (UNISO), Maria Lilia Dias de Castro (UFMS), Mariangela Haswani (USP), Mitsuru Yanaze (USP), Pedro Hellín (Universidade de Múrcia- ES), Paulo Lencastre (Universidade Católica do Porto-PT), Sandra Maria Ribeiro de Souza (USP), Sergio Trein (UNISINOS), Tania Hoff (ESPMSP).

Desejamos a todos uma ótima leitura.

Os Editores 